\title{
Concentrations and Speciation of Mercury in Soil Affected by Bird Droppings
}

\author{
Youru Yao ${ }^{1}$, Fengman Fang ${ }^{1,2 *}$, Huijun $\mathbf{W u}^{1}$, Minghong $\mathbf{W u}^{1}$, \\ Ying Kuang ${ }^{1}$, Yuesheng Lin ${ }^{1,2}$ \\ ${ }^{1}$ College of Geography and Tourism, Anhui Normal University, Wuhu, China \\ ${ }^{2}$ Key Laboratory of Earth Surface Processes and Regional Response in the Yangtze-Huaihe River Basin, \\ Anhui Province, Wuhu, China
}

Received: 13 December 2017

Accepted: 20 March 2018

\begin{abstract}
This study investigates the effects of bird droppings on mercury pollution levels in soil, specifically on the speciation and total concentration of mercury $(\mathrm{Hg})$ in soil from Tongli Wetland, East China. Thirty soil samples and four bird dropping samples were collected from Tongli Wetland along with fifteen eggshells and five feathers from Heron Branch birds. Results indicated that bird droppings affect local soil's physic-chemical properties and $\mathrm{Hg}$ accumulation. Additionally, heron feathers were found to contain more total mercury $(\mathrm{HgT})$ than their eggshells. $\mathrm{Hg}$ concentration in soil that is affected by bird dropping was determined to be $0.194 \pm 0.026 \mathrm{mg} / \mathrm{kg}$; concentration in soil without bird droppings was $0.104 \pm 0.039 \mathrm{mg} / \mathrm{kg}$. Therefore, $\mathrm{HgT}$ concentration in the former exceeded that of the latter $(86.54 \%)$. Numerical analysis revealed that concentrations of water-soluble (F1), acid-soluble (F2), alkali-soluble (F3), hydrogen peroxide-soluble (F4), and residual mercury (F5) in soil that is affected by bird dropping were higher in soil that isn't affected by bird droppings. However, concentrations of F1 remained mostly stable. We found a positive correlation between $\mathrm{Hg}$ concentrations in soil and excrement and concentrations of total carbon $\left(\mathrm{C}_{\mathrm{tot}}\right)$, total nitrogen $\left(\mathrm{N}_{\mathrm{tot}}\right)$, and hydrogen $(\mathrm{H})$, in addition to an exponential proportional relationship between $\mathrm{C} / \mathrm{N}$ and $\mathrm{Hg} / \mathrm{C}$. We concluded that fresh bird droppings in soil may promote mercury enrichment. Furthermore, bird droppings and highly decomposed humus increase soil $\mathrm{HgT}$ concentration when they remain in soil for an extended period of time.
\end{abstract}

Keywords: mercury and mercury speciation, bird droppings, soil contamination, wetland

\section{Introduction}

Mercury $(\mathrm{Hg})$ is a type of nervous poison element that exists in the atmosphere, water, and soil. It can threaten human health and the greater ecosystem

*e-mail: ffm1974@mail.ahnu.edu.cn either directly or indirectly [1-3]. For example, when consumed through food, high concentrations of mercury and methyl-mercury ( $\mathrm{MeHg}$ ) may affect humans' and animals' nervous and reproductive systems. In addition, $\mathrm{Hg}$ and $\mathrm{MeHg}$ can change birds' sexual orientation by disrupting the release of gonadal hormones, and bring into play adverse effects such as endocrine disruption and neurodevelopmental impairment in carnivores 
[4-6]. These poisonous elements can also affect a plants' physiological activities [6-7]. As a result, the United States Environmental Protection Agency has defined Hg as highly dangerous [8].

Wetlands refer to regions that are either temporarily or permanently flooded, leading to anoxic conditions and subsequent bio-reduction of soil. Natural or artificial sources of heavy metals can enter the wetland ecosystem from the ground surface, underground runoff, and atmospheric dust, and can be enriched in the body of fish [9-11]. When hydrological conditions and physicochemical properties in wetland soil, sediment, and water are changed, some of the heavy metal and mercury that has been fixed will be released again, resulting in secondary pollution and deterioration of the ecological environment [12-14]. Wetland soil is an important interface between aquatic and terrestrial ecosystems in which mercury often accumulates and transspecies [15-16]. Many birds frequent wetlands; in fact, they are highest on the wetland ecosystem's food chain. Because mercury produces biological amplification throughout the food chain and accumulates over time, $\mathrm{Hg}$ concentrations are universally greater in higher trophic level birds than in others [17]. Mercury pollution also alters birds' ecological interactions, habitats, food chains, community structures, and species [18]. Studies have shown that $\mathrm{Hg}$ concentrations are higher in bird feathers and excrement than muscle and internal organs [19]. These concentrations are analogous to the amount of mercury in the environment $[17-18,20]$.

Various bird activities influence mercury pollution in the environment. For instance, Liu et al. [20] reported that $\mathrm{Hg}$ concentrations in soil samples containing seabird droppings were significantly higher than in samples without bird droppings. Trophic level significantly affected $\mathrm{Hg}$ transfer efficiency in seabirds [21]. However, few studies have investigated the impact of bird activities on $\mathrm{Hg}$ concentrations in the local environments of mainland wetlands and forests. This paper therefore aims to examine $\mathrm{Hg}$ enrichment from different media between birds in the internal land ecosystem, the effects of bird droppings on the local soil's $\mathrm{Hg}$ concentration, and bird droppings' influence on the chemical speciation of mercury in soil.

\section{Materials and Methods}

\section{Study Area}

Tongli Wetland is located in the city of Wujiang in Jiangsu Province in eastern China. The wetland covers an area of nearly $690 \mathrm{hm}^{2}$, of which water comprises $240 \mathrm{hm}^{2}$ along with land coverage of $450 \mathrm{hm}^{2}$. In 2009 the Jiangsu Provincial Environmental Protection Office announced regional planning of the important ecological functional reserve as permanent restrictions in the city development area that restrict industrial and agricultural activities. And the pre-sampling survey also shows that the wetland had no industrial or agricultural activities. It is a good research area because it is less disturbed by artificial activities. The wetland has a diverse ecosystem with 170 species of plants, including ginkgo, metasequoia, and others; and a bird distribution consisting of 12 orders, 28 families, and 91 species (e.g., egrets, kingfishers, herons, etc.).

\section{Sampling and Pretreatment}

Soil composition: The soil type in this study area is waterlogged paddy, the main component is yellow pine soil, and the soil is viscous. It is formed by the accumulation of alluvial loamy parent material derived from the lake deposition. The soil is brownish yellow with a waterlogging layer typical development, and the edge block structure is obvious. At the same time, the structure surface has the continuous grey film and the section is covered with iron manganese rust spots. The soil in the forest zone is rich in dead branches and deciduous leaves, which makes it have an appreciable amount of organic matter and humus.

Soil samples were collected using a grid method $(500 \times 500 \mathrm{~m})$ points, coarctation, or sparseness sampling depending on local topography and river development. For the purposes of this study, a soil sample refers to the mixture of a middle sampling point and four subsamples from four corners (south, north, east, and west) taken from the same sample site. Soil was sampled from the soil surface to $15 \mathrm{~cm}$ depth [18], and the weight of each mixed homogeneous soil sample was approximately $1 \mathrm{~kg}$. We collected a total of 30 soil samples in Tongli Wetland: 15 soil samples that are affected by bird droppings (WS) (note: bird droppings covering the surface of the soil were removed in the process of collecting soil samples, so the soil does not contain bird droppings) and 15 soil samples that are not affected by bird droppings (OS) (Fig. 1). Bird droppings (BS) that covered the soil surface about $1-2 \mathrm{~cm}$ thick were gathered from four sites. A quadruplicate method was used to remove excess samples; 100-200 g of bird droppings were retained in total. In areas where bird activity is frequent, 15 fresh heron branch bird eggshells (ES) and 4 feathers (FS) were picked and placed in its own separate polyethylene plastic bags. All samples were from the heron branch family. All samples were collected during the summer.

After collection, soil and excrement samples were air-dried in the laboratory. All stones, plant root systems, organic residue, and visible invaders were removed. Then each sample was passed through a $0.85 \mathrm{~mm}$ mesh nylon sieve before being ground using an agate mortar and passed through a $0.15 \mathrm{~mm}$ mesh nylon sieve. In treating the eggshell samples, all residue was removed from the shell surface using a soft brush, after which samples were rinsed for 10 minutes with an ultrasonic cleaning device. Next, samples were washed 3-5 times with ultrapure water and then placed in a beaker and put into an oven to dry for 12 hours at $60^{\circ} \mathrm{C}$. Finally, 


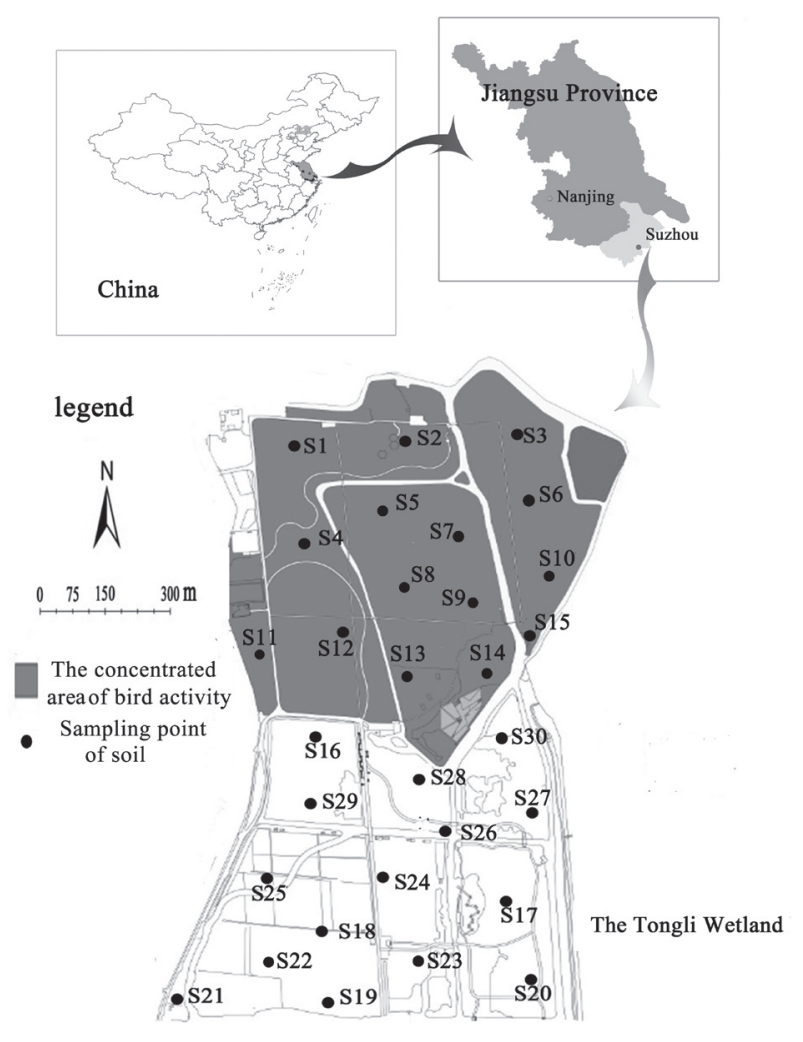

Fig. 1. The map of sampling point.

dried samples were ground with an agate mortar and were passed through a sieve that is less than $0.15 \mathrm{~mm}$ in diameter and placed into new polyethylene plastic bags. The four feather samples were treated similarly to the eggshell samples, but in the final step dried feathers were cut using plastic scissors prior to being placed in plastic film bags.

\section{Experimental Methods}

\section{Analysis of Physic-Chemical Properties}

Total carbon $\left(\mathrm{C}_{\text {tot }}\right)$, nitrogen $\left(\mathrm{N}_{\text {tot }}\right)$, sulphur $\left(\mathrm{S}_{\text {tot }}\right)$, and hydrogen $(\mathrm{H})$ contents were measured in homogenized samples using an Elementar CHNS Elemental Analyzer at a combustion tube temperature of $1150^{\circ} \mathrm{C}$ and reduction tube temperature of $850^{\circ} \mathrm{C}$. The method for determining total organic carbon (TOC) in soils and bird dropping samples was by dichromate oxidationouter heating.

\section{HgT Determination in Soil Sediment and Excrement}

$0.2000 \mathrm{~g}$ of soil and excrement samples were weighed in a $50 \mathrm{~mL}$ flask to which $20 \mathrm{~mL}$ aqua regia (3:1:4 $\left.\mathrm{HCl}: \mathrm{HNO}_{3}: \mathrm{H}_{2} \mathrm{O}\right)$ was added. Then the mixture was heated for 2 hours in a $95^{\circ} \mathrm{C}$ water bath and shaken every 20 minutes. After cooling, the mixture was diluted to $50 \mathrm{~mL}$ using $0.5 \% \mathrm{HNO}_{3}+0.05 \%$ $\mathrm{K}_{2} \mathrm{Cr}_{2} \mathrm{O}_{7}$ [22]. Using AFS-820 double channel atomic fluorescence spectrometry with a hollow cathode lamp of mercury and high purity argon gas, $\mathrm{Hg}$ concentration in the resultant solution was determined to be $5 \% \mathrm{HCl}$ with $2 \% \mathrm{KBH}_{4}(\mathrm{w} / \mathrm{v})+0.5 \% \mathrm{KOH}(\mathrm{w} / \mathrm{v})$ as the reducing agent.

\section{HgT Determination in Eggshells and Feathers}

$0.4000 \mathrm{~g}$ of eggshell and feather samples were weighed in a $50 \mathrm{~mL}$ flask to which $20 \mathrm{~mL}$ mixed acid (8:2 $\left.\mathrm{HNO}_{3}: \mathrm{HClO}_{4}\right)$ was added using a small funnel. All samples were left overnight. Then, they were placed on an electric furnace and heated at $120^{\circ} \mathrm{C}$ until the solution became colorless and clarified. The solution was then removed and cooled to room temperature, at which point the mixture was diluted to $50 \mathrm{~mL}$ using $0.5 \% \mathrm{HNO}_{3}$. $\mathrm{Hg}$ concentration in chemical species was determined using the same method as outlined in section 2.3.2.

\section{Extraction and Determination of Mercury Speciation}

The concentration of HgT in soil and excrement is the sum of Hg's different chemical species, which can be differentiated by chemical and physical behavior [23]. For Hg speciation, a five-step selective sequential extraction procedure was applied; we followed the method developed by Zhang et al. [24]. Extractions were carried out using $1.000 \mathrm{~g}$ of samples. Five fractions were distinguished: (1) water-soluble (F1); (2) acid-soluble (F2); (3) alkali-soluble (F3); and (4) hydrogen peroxidesoluble (F4). In step 5, residue digestion with aqua regia was perspeciesed for mercuric sulfide (F5). As with $\mathrm{HgT}$ determination, $\mathrm{Hg}$ speciation was measured using AFS-820 double-channel atomic fluorescence spectrometry.

\section{Quality Control}

Glassware used during sample analysis was placed in $10 \% \mathrm{HNO}_{3}(\mathrm{v} / \mathrm{v})$ immersion for over 24 hours and was sanitized according to procedures suggested by Fang [22]. GBW07403 (GSS-3) certified reference materials were added in the digestion process to ensure quality and accurate measurements. These results are listed in Table 1. Quality control also included the use of blanks (6 blank samples for 30 soil samples) and 3 duplicate samples analyzed in each digestion batch (25 samples per batch). The instrument's Hg detection limit was $0.001 \mathrm{ng} / \mathrm{mL}$; these results confirmed that the $\mathrm{Hg}$ analysis was sufficiently credible for our study.

\section{Data Snalysis}

All data were analyzed in Excel 2010 and SPSS 20.0. Non-parametric tests and Kruskal-Wallis tests were used to evaluate the effects of bird droppings on soil 
Table 1. Parameters and determination about standard sample $( \pm$ standard deviation $)(\mathrm{mg} / \mathrm{kg})$.

\begin{tabular}{|c|c|c|c|}
\hline & $\begin{array}{c}\text { Certified } \\
\text { values }\end{array}$ & $\begin{array}{c}\text { Actual measured } \\
\text { value }\end{array}$ & $\begin{array}{c}\text { Measurement } \\
\text { times }\end{array}$ \\
\hline GSS-3 & $0.060 \pm 0.004$ & $0.069 \pm 0.003$ & 12 \\
\hline
\end{tabular}

samples' HgT concentrations and chemical species at a 0.05 significance level for all analyses.

\section{Results and Discussion}

\section{Physical and Chemical Characteristics of Soil and Excrement}

The average $\mathrm{pH}$ value of soil samples taken from Tongli Wetland was 4.9 (i.e., acidic). The $\mathrm{pH}$ value of OS was significantly higher than that of WS $(\mathrm{P} \approx 0.005<0.05$ ) by $13.04 \%$ (see Table 2 ). The average content of $\mathrm{C}_{\text {tot }}, \mathrm{N}_{\text {tot }}, \mathrm{S}_{\text {tot }}$, and $\mathrm{H}$ in wetland soil was higher than that of soil in typical subtropical regions, reaching $2.72,24.37,9.93$, and $0.69 \mathrm{~g} \cdot \mathrm{kg}^{-1}$, respectively. The content of TOC is $0.04 \pm 0.01 \mathrm{~g}^{\circ} \mathrm{kg}^{-1}$. The average content of $\mathrm{S}_{\text {tot }}$ in WS and OS was significantly different $(\mathrm{P} \approx 0.000<0.01): \mathrm{S}_{\text {tot }}$ content in WS was $104.86 \%$ higher than in OS. Similarly, the average content of $\mathrm{N}_{\text {tot }}$ in WS was significantly higher than in OS $(\mathrm{P}=0.037<0.05)$ by $22.95 \%$. The same appeared to be true of $\mathrm{C}_{\text {tot }}$ and $\mathrm{H}$ content: those in WS were higher than in OS, although we found no noteworthy statistical differences. The same appeared to be true of TOC in WS, which were higher than in OS, although we found no noteworthy statistical differences. This indicates that the nutrients in the soil are different in the WS and OS.

The $\mathrm{pH}$ value of BS (4.6) also indicated acidity, and its concentrations of $\mathrm{C}_{\text {tot }}, \mathrm{N}_{\mathrm{tot}}$, and $\mathrm{H}$ were higher than those found in OS and WS. We found similar results for $\mathrm{C} / \mathrm{N}$ and $\mathrm{C} / \mathrm{H}$. The concentration of $\mathrm{S}_{\text {tot }}$ in $\mathrm{BS}$ was higher than in OS but slightly lower than in WS.
Regarding differences between WS and OS specifically in the soil samples, $\mathrm{C}_{\text {tot }}, \mathrm{N}_{\text {tot }}$, TOC, and $\mathrm{H}$ concentrations in WS were higher than in OS. Therefore, once nutrient-rich bird droppings enter into the soil, $\mathrm{C}_{\text {tot }}$, $\mathrm{N}_{\text {tot }}$, TOC, and $\mathrm{H}$ content will increase, because the bird droppings that have higher nutrient content have been affecting the soil. When bird droppings remain in soil for a long time, organic matter and humus content increase accordingly. Organic acids secreted by plants can aggravate soil acidification, resulting in lower $\mathrm{pH}$ values.

\section{Distribution Characteristics of $\mathrm{HgT}$ Concentrations in Different Media}

As presented in Fig. 2, there were clear variations in $\mathrm{Hg}$ concentrations across different media. For OS, the results suggested that the average $\mathrm{HgT}$ concentration was $0.104 \pm 0.032 \mathrm{mg} / \mathrm{kg}$. In comparison, $\mathrm{Hg}$ concentrations in WS and BS were higher than in OS at $0.194 \pm 0.155$ and $0.182 \pm 0.020 \mathrm{mg} / \mathrm{kg}$, respectively. In line with the environmental quality standard for soils in China (GB 15618-1995), Hg concentration in one soil sample (6.67\%) exceeded Grade 1 of GB 15618-1995 $(0.15 \mathrm{mg} / \mathrm{kg})($ Grade 1 is the standard that is a limiting value in order to maintain the soil environment quality of the natural background in China). There were 4 WS samples with $\mathrm{HgT}$ concentrations above the standard value (i.e., with standard ratios in excess of $22.67 \%$ ). The HgT concentration of all BS samples also exceeded the standard value (i.e., with standard ratios exceeding $100 \%)$. The concentration of $\mathrm{HgT}$ of the soil in this study area was compared with soil background value of mercury in the local $(0.163 \mu \mathrm{g} / \mathrm{g})$ [25], the phenomenon of enrichment is present in the WS, but is not found in the OS.

In ES, the average $\mathrm{Hg}$ concentration was $0.021 \pm 0.013 \mathrm{mg} / \mathrm{kg}$. The average $\mathrm{Hg}$ concentration in feathers was higher at $0.071 \pm 0.023 \mathrm{mg} / \mathrm{kg}$; thus, $\mathrm{HgT}$ enrichment from feathers was greater than from eggshells. Research has shown that $\mathrm{Hg}$ concentration

Table 2. Physical and chemical characters in soil and excrements from Tongli in summer.

\begin{tabular}{|c|c|c|c|c|c|c|c|}
\hline & & $\mathrm{pH}$ & $\mathrm{N}_{\mathrm{tot}}(\mathrm{g} / \mathrm{kg})$ & $\mathrm{C}_{\mathrm{tot}}(\mathrm{g} / \mathrm{kg})$ & $\mathrm{H}(\mathrm{g} / \mathrm{kg})$ & $\mathrm{S}_{\mathrm{tot}}(\mathrm{g} / \mathrm{kg})$ & $\mathrm{TOC}(\mathrm{g} / \mathrm{kg})$ \\
\hline \multirow{3}{*}{$\begin{array}{c}\text { OS } \\
(\mathrm{n}=15)\end{array}$} & Average Content & 5.2 & 2.44 & 22.67 & 9.65 & 0.45 & 0.03 \\
\cline { 2 - 9 } & Standard Deviation & 0.8 & 0.82 & 8.87 & 2.13 & 0.14 & 0.01 \\
\hline & Coefficient of Variation (\%) & 15.38 & 33.61 & 39.13 & 22.07 & 31.11 & 33.33 \\
\hline \multirow{3}{*}{$\begin{array}{c}\text { WS } \\
(\mathrm{n}=15)\end{array}$} & Average Content & 4.6 & 3.00 & 26.06 & 10.21 & 0.93 & 0.04 \\
\cline { 2 - 9 } & Standard Deviation & 0.8 & 0.77 & 8.90 & 1.53 & 0.28 & 0.01 \\
\hline \multirow{3}{*}{$\begin{array}{c}B S \\
(n=4)\end{array}$} & Coefficient of Variation (\%) & 17.39 & 25.67 & 34.15 & 14.99 & 30.11 & 0.25 \\
\cline { 2 - 9 } & Average Content & 4.6 & 6.24 & 81.50 & 15.34 & 0.70 & 0.08 \\
\cline { 2 - 9 } & Standard Deviation & 0.2 & 1.48 & 26.06 & 3.55 & 0.21 & 0.01 \\
\hline
\end{tabular}




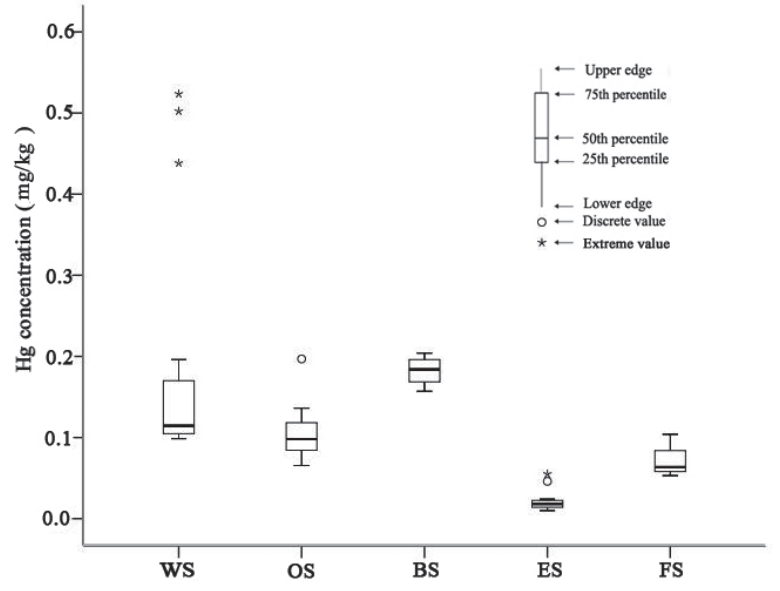

Fig. 2. Spatial distribution characteristics of $\mathrm{Hg}$ from different media

in feathers is responsible for $93 \%$ of $\mathrm{Hg}$ in a bird's body [12]. It is important to note that different migration stopovers may convolute the interpretation and utility of $\mathrm{HgT}$ concentration in bird feathers as an indicator of $\mathrm{Hg}$ exposure in the sampling area [11, 26-27]. Because there were higher $\mathrm{Hg}$ concentrations in feathers than in eggshells in this study, we can derive information about $\mathrm{Hg}$ in the local environment; namely, $\mathrm{Hg}$ in feathers represents circulating concentrations in the blood during a brief period of feather speciation, which in turn indicates local exposure and mobilization from internal tissues [28]. Once feathers mature, their vascular connection atrophies, leaving the feather as a record of blood levels at the point of speciation. The concentration of metals in feathers, however, remains constant [29]. This explains why feathers could absorb mercury in a bird's body. However, due to a lack of albumen, vitelline, and embryo, eggshells can only retain part of a birds' $\mathrm{Hg}$ speciation, rendering feathers a more accurate representation of $\mathrm{Hg}$ levels.

The results showed that WS and BS are highlighted differences from OS by Non-parametric and Kruskal-Wallis tests. In particular, significant differences were found between OS and WS $(\mathrm{P}=0.044<0.05)$ and $\mathrm{OS}$ and $\mathrm{BS}(\mathrm{P}=0.011<0.05)$; the difference between WS and BS was not statistically significant. $\mathrm{Hg}_{\mathrm{T}}$ concentration in BS was significantly higher than in WS, echoing previous research findings [20-21]. Because $\mathrm{Hg}$ is a typical heavy metal element with biological enrichment characteristics [30], it can be absorbed in a bird's body and thus appear in excrement [21, 31]. Excrement represents unabsorbed remnants of multiple food items, often at higher concentrations than multiple food items, to provide a non-destructive, quantifiable means of monitoring $\mathrm{Hg}$ contamination in the food chain [31].

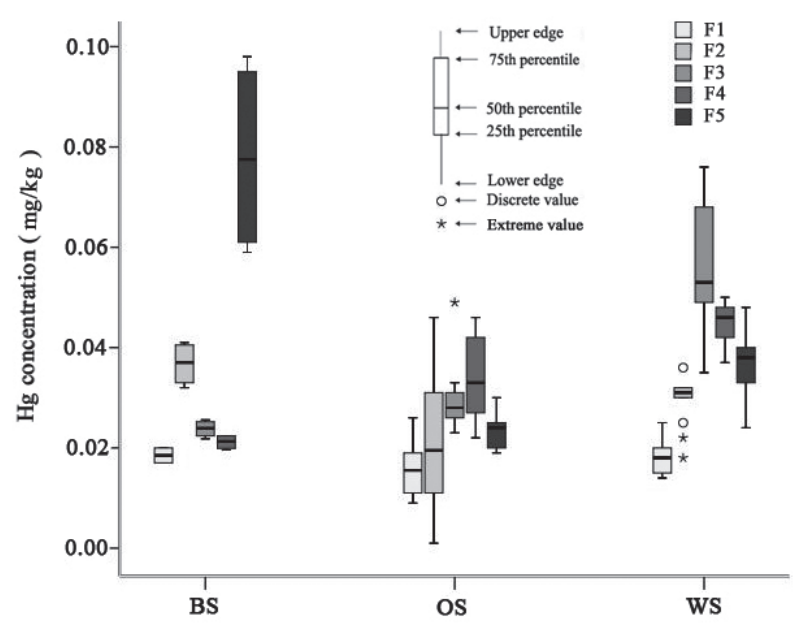

Fig. 3. Distribution of $\mathrm{Hg}$ speciation in soil and excrements Note: F1: Water-soluble mercury, F2: Acid-soluble mercury, F3: Alkali-soluble mercury, F4: Hydrogen peroxide-soluble mercury, F5: Residual mercury; BS: Samples of bird droppings, OS: Soil samples that are not affected by bird droppings, WS: Soil samples that are affected by bird droppings.

\section{Chemical Speciation Analysis of $\mathrm{Hg}$ in Soil and Excrement}

In $\mathrm{OS}, \mathrm{Hg}$ concentrations in different speciation (i.e., F1, F2, F3, F4, and F5) were $0.015 \pm 0.005$, $0.022 \pm 0.016, \quad 0.030 \pm 0.006, \quad 0.034 \pm 0.008, \quad$ and $0.024 \pm 0.003 \mathrm{mg} / \mathrm{kg}$, respectively. In WS, $\mathrm{Hg}$ concentrations in different speciation were $0.018 \pm 0.004$, $0.029 \pm 0.005, \quad 0.052 \pm 0.015, \quad 0.043 \pm 0.006, \quad$ and $0.035 \pm 0.008 \mathrm{mg} / \mathrm{kg}$. In BS, concentrations were $0.019 \pm 0.002, \quad 0.037 \pm 0.008, \quad 0.024 \pm 0.002, \quad 0.021 \pm 0.001$, and $0.078 \pm 0.020 \mathrm{mg} / \mathrm{kg}$ (see Fig. 3).

Distinct characteristics appeared in different chemical species of $\mathrm{Hg}$ across OS, WS, and BS. The concentration of F1 was basically equal in OS and WS. However, the concentrations of F2, F3, F4, and F5 in WS were higher than in OS by ratios of $31.8 \%, 73.3 \%, 26.5 \%$, and $45.8 \%$, respectively. When comparing BS with WS, we found a slight difference in the concentration of $\mathrm{Hg}$ in F1. In F3 and F4, by comparing BS with WS, $\mathrm{Hg}$ concentrations in WS were higher than in BS at ratios of $116.7 \%$ and $104.8 \%$, respectively. However, $\mathrm{Hg}$ concentrations of F2 and F5 in BS were higher than in WS at ratios of $27.6 \%$ and $122.9 \%$.

The above results provide interesting insight. In its natural state, excrement from Ardeid birds as found in soil increases the $\mathrm{HgT}$ concentration of surface soil. More than that, though, increased $\mathrm{Hg}$ concentrations were also found in the three chemical species (i.e., water-soluble, acid-soluble, and residual mercury) possibly due to chemical species trans-speciation from residual mercury to available mercury in bird droppings under acidic soil and microbial activity conditions. 
Table 3. Correlation between mercury and physico-chemical properties.

\begin{tabular}{|c|c|c|c|c|c|c|c|}
\hline & $\mathrm{N}_{\text {tot }}$ & $\mathrm{C}_{\text {tot }}$ & $\mathrm{H}$ & $\mathrm{S}_{\text {tot }}$ & $\mathrm{Hg}_{\mathrm{T}}$ & $\mathrm{pH}$ & $\mathrm{TOC}$ \\
\hline $\mathrm{N}_{\text {tot }}$ & 1.000 & & & & & & \\
\hline $\mathrm{C}_{\text {tot }}$ & $0.936^{* *}$ & 1.000 & & & & & \\
\hline $\mathrm{H}$ & $0.877^{* *}$ & $0.899^{* *}$ & 1.000 & & & & \\
\hline $\mathrm{S}_{\text {tot }}$ & $0.430^{*}$ & $0.373^{*}$ & $0.363^{*}$ & 1.000 & & & \\
\hline $\mathrm{Hg}_{\mathrm{T}}$ & $0.677^{* *}$ & $0.530^{* *}$ & $0.432^{*}$ & 0.316 & 1.000 & & \\
\hline $\mathrm{pH}$ & $-0.340^{*}$ & -0.300 & $-0.352^{*}$ & $-0.769^{* *}$ & -0.079 & 1.000 & \\
\hline $\mathrm{TOC}$ & $0.773^{* *}$ & $0.732^{* *}$ & $0.675^{* *}$ & $0.547^{* *}$ & $0.409^{*}$ & $-0.423^{*}$ & 1.000 \\
\hline
\end{tabular}

Note: ${ }^{* *}$ The correlation is extremely significant when the confidence level is 0.01 . ${ }^{*}$ The correlation is significant when the confidence level is 0.05 .

And studies have shown that it is easy for water- and acid-soluble mercury to transport and transform, with the $\mathrm{pH}$ and Eh changes in soil, their concentration in the soil would change [24].

Because soil in Tongli Wetland is typically acidic and covered in bird droppings, $\mathrm{Hg}$ in droppings leaches readily into the soil surface as it rains. Studies have shown that Hg's migration efficiency is enhanced when there is acidity and high concentrations of organic matter [32].

\section{Correlation between $\mathrm{Hg}$ and Physic-Chemical Properties}

A Spearman rank correlation was used to analyze the correlation between $\mathrm{Hg}$ and physico-chemical properties (see Table 3). There was an extremely significant correlation between concentrations of $\mathrm{HgT}$ and $\mathrm{N}_{\text {tot }}$ and $\mathrm{C}_{\text {tot }}$ in soil and excrement ( $\rho=0.677,0.530$, $\mathrm{p}<0.01)$. We also found a significant correlation between concentrations of $\mathrm{HgT}$ and $\mathrm{H}$ in soil and excrement $(\rho=0.432, p<0.05)$.

Similar studies are consistent with the results of this study. Some studies have shown that there is a significant correlation between TOC, total Carbon, and total $\mathrm{Hg}$ in forest soils and sediments [33]. The results showed that TOC, $\mathrm{C}_{\text {tot }}, \mathrm{N}_{\text {tot }}$, and $\mathrm{H}$ in soil and bird droppings were positively correlated with $\mathrm{HgT}$ in soil and bird droppings, and higher concentrations of TOC, $\mathrm{C}_{\text {tot }}, \mathrm{N}_{\text {tot }}$, and $\mathrm{H}$ could enhance the concentration of HgT in soil. Studies have shown that organic matter has a great effect on soil adsorption and fixation of $\mathrm{Hg}$, the soil organic matter increases by $1 \%$, and the fixed rate of $\mathrm{Hg}$ can reach $30 \%$ or so. Organic matter and humus in soil have a strong binding effect on $\mathrm{Hg}$ by adsorption, desorption, complexation, chelation, etc., thus affecting the absorption and transfer of $\mathrm{Hg}$ in soil [34]. Therefore, in the soil background with high organic matter content, the content of $\mathrm{Hg}$ is also high, and there are good correlations between $\mathrm{Hg}$ and TOC, and $\mathrm{N}_{\text {tot }}$ and $\mathrm{C}_{\text {tot }}$ in soil sediments. The entry of bird droppings will increase the content of $\mathrm{N}_{\text {tot }}, \mathrm{C}_{\text {tot }}$, and TOC in the soil, over time, and with the microbial activity its nutrient elements will be converted to organic matter and humus, which would increase the adsorption of $\mathrm{Hg}$ in sediment and soil and increase the concentration of $\mathrm{Hg}$.

HgT concentrations in soil and excrement were further positively correlated with $\mathrm{N}_{\text {tot }}, \mathrm{H}$, and C. C/N ratios indicate the degree of decomposition: high $\mathrm{C} / \mathrm{N}$ ratios represent fresh, undecomposed organic $\mathrm{C}$, while low $\mathrm{C} / \mathrm{N}$ ratios are indicative of older, decomposed fractions [33]. $\mathrm{Hg} / \mathrm{C}$ ratios increase exponentially with decreasing $\mathrm{C} / \mathrm{N}$ ratios (see Fig. 4). Possible reasons for increasing $\mathrm{Hg}$ and $\mathrm{Hg} / \mathrm{C}$ levels in decomposing excrements and $\mathrm{C}$ pools include selective $\mathrm{Hg}$ sorption to different organic matter fractions [33, 35]. Fresh bird droppings could promote mercury enrichment in soil. As time goes by, bird droppings and humus that are highly decomposed will likely increase $\mathrm{HgT}$ concentration in soil when they remain there for an extended period, which explains why $\mathrm{Hg}$ concentrations were higher in WS than in OS. In terms of the relationship between $\mathrm{Hg}$ and $\mathrm{H}$ content in soil, if $\mathrm{H}$ concentration increases, it can promote the growth of plants and rhizospherehydrogenated bacteria [36]. The same can be said for organic matter loss slowing and increasing in alkali-

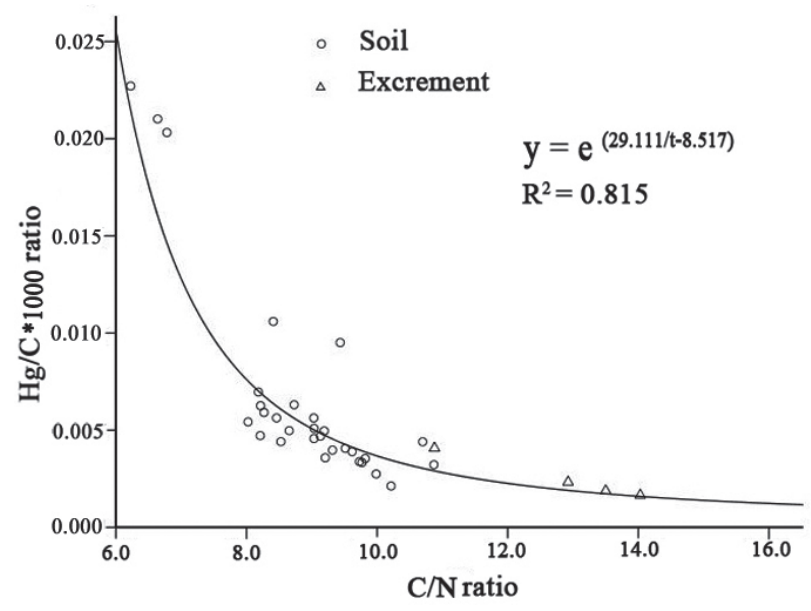

Fig. 4. Hg to $\mathrm{C} / \mathrm{N}$ relationships observed in soils and excrements. 
Table 4. Correlation between speciation of mercury and physico-chemical properties.

\begin{tabular}{|c|c|c|c|c|c|c|c|c|c|c|c|}
\hline & TOC & $\mathrm{pH}$ & $\mathrm{N}_{\text {tot }}$ & $\mathrm{C}_{\text {tot }}$ & $\mathrm{H}$ & $\mathrm{S}_{\text {tot }}$ & $\mathrm{F} 1$ & $\mathrm{~F} 2$ & $\mathrm{~F} 3$ & $\mathrm{~F} 4$ & $\mathrm{~F} 5$ \\
\hline $\mathrm{TOC}$ & 1 & & & & & & & & & & \\
\hline $\mathrm{pH}$ & -0.081 & 1 & & & & & & & & & \\
\hline $\mathrm{N}_{\text {tot }}$ & $0.584^{* *}$ & -0.251 & 1 & & & & & & & & \\
\hline $\mathrm{C}_{\text {tot }}$ & $0.460^{*}$ & -0.314 & $0.918^{* *}$ & 1 & & & & & & & \\
\hline $\mathrm{H}$ & $0.395^{*}$ & -0.332 & $0.840^{* *}$ & $0.872^{* *}$ & 1 & & & & & & \\
\hline $\mathrm{S}_{\text {tot }}$ & $0.471^{* *}$ & $-0.630^{* *}$ & $0.411^{*}$ & $0.419^{*}$ & 0.281 & 1 & & & & & \\
\hline $\mathrm{F} 1$ & 0.137 & -0.325 & -0.056 & 0.060 & 0.095 & 0.331 & 1 & & & & \\
\hline $\mathrm{F} 2$ & 0.326 & $0.376^{*}$ & 0.347 & 0.053 & 0.119 & -0.187 & -0.213 & 1 & & & \\
\hline $\mathrm{F} 3$ & 0.352 & $-0.588^{* *}$ & 0.185 & 0.133 & 0.169 & $0.677^{* *}$ & $0.369^{*}$ & -0.120 & 1 & \\
\hline F4 & $0.411^{*}$ & $-0.607^{* *}$ & 0.265 & 0.244 & 0.331 & $0.679^{* *}$ & 0.198 & -0.175 & $0.673^{* *}$ & 1 & 1 \\
\hline F5 & $0.379^{*}$ & $-0.522^{* *}$ & 0.192 & 0.129 & 0.039 & $0.838^{* *}$ & 0.288 & -0.150 & $0.786^{* *}$ & $0.634^{* *}$ & 1 \\
\hline
\end{tabular}

Note: ${ }^{* *}$ The correlation is extremely significant when the confidence level is 0.01 . ${ }^{*}$ The correlation is significant when the confidence level is 0.05. F1: Water-soluble mercury, F2: Acid-soluble mercury, F3: Alkali-soluble mercury, F4: Hydrogen peroxide-soluble mercury, F5: Residual mercury.

hydrolyzable nitrogen, urease activity, nitrogen fixation, and ammonification. Due to high $\mathrm{H}$ concentrations in excrement in the sampled soil, nutrient elements could increase and thus facilitate growth of plant root systems and promote absorption of available mercury from soil and excrement. Therefore, $\mathrm{Hg}$ concentration in WS compared to OS was small in F1, but higher in F2, F3, $\mathrm{F} 4$, and F5.

Correlation analysis between physical and chemical properties and $\mathrm{Hg}$ speciation in the soil (Table 4) shows a significant positive correlation between TOC and $\mathrm{F} 4$, while $\mathrm{pH}$ exhibits significant negative correlation with F3, F4, and F5; $\mathrm{pH}$ was positively correlated with F2, S and F3, F4 and F5 showed significant positive correlations. It is indicated that the contents of TOC, $\mathrm{C}_{\text {tot }}, \mathrm{N}_{\text {tot }}, \mathrm{H}$, and Stot in soil and bird droppings affect the change of $\mathrm{Hg}$ speciation - especially the effect on the available state (the sum of the concentration of F1, F2, F3, and F4) being greater, but the influence of the residue state $\mathrm{Hg}$ (the concentration of F5) is not statistically significant.

The correlation analysis of $\mathrm{Hg}$ speciation in soil showed that there was a significant positive correlation between F1 and F3, F3 and F4 and F5 showed significant positive correlations, similarly; there was also a significant positive correlation between F4 and F5. The results showed that there may be a transformation between the available states of mercury. Meanwhile, there is also a possibility for mutual transformation between the available states and the residual state of mercury.

\section{Conclusions}

Bird droppings influence the physico-chemical properties and accumulation of $\mathrm{Hg}$ in Tongli Wetland soil. Hg enrichment from heron branch bird feathers is stronger than $\mathrm{HgT}$ concentrations in eggshells. Accompanied by bird activity, HgT concentrations in soil will increase, thereby rendering $\mathrm{HgT}$ concentrations in soil with bird droppings higher than in soil without. Numerical analysis revealed that concentrations of water-soluble, acid-soluble, alkali-soluble, hydrogen peroxide-soluble, and residual mercury in soil that is affected by bird droppings were higher in soil that is not affected by bird droppings. Thus, we can conclude that a positive correlation exists between $\mathrm{Hg}$ concentrations in soil or excrement and $\mathrm{C}_{\text {tot }}, \mathrm{N}_{\text {tot }}$, and $\mathrm{H}$ concentrations. Furthermore, there is an exponential proportional relationship between $\mathrm{C} / \mathrm{N}$ and $\mathrm{Hg} / \mathrm{C}$. Fresh bird droppings may promote $\mathrm{Hg}$ enrichment in soil. Over time, highly decomposed bird droppings and humus are likely to be more conducive to $\mathrm{Hg}$ accumulation than when bird droppings first enter the soil.

\section{Acknowledgements}

The revision of this article was assisted by Associate Professor Wu Li from the College of Geography and Tourism at Anhui Normal University. The authors gratefully acknowledge the financial support of the National Natural Science Foundation of China (No. 41371480). 


\section{Conflict of Interest}

The authors declare no conflict of interest

\section{References}

1. BERNALTE E., SANCHEZ C.M., GIL E.P. Highthroughput mercury monitoring in indoor dust microsamples by bath ultrasonic extraction and anodic stripping voltammetry on gold nanoparticles-modified screen-printed electrodes. Electroanalysis. 25, 289, 2013.

2. NG K., SZABO Z., REILLY P.A., BARRINGER J.L., SMALLING K. L. An assessment of mercury in estuarine sediment and tissue in Southern New Jersey using public domain data. Marine Pollution Bulletin. 107, 22, 2016.

3. RAJAEE M., LONG R.N., RENNE E.P., BASU N. Mercury exposure assessment and spatial distribution in a Ghanaian small-scale gold mining community. International Journal of Environmental Research and Public Health. 12, 10755, 2015.

4. CARRAVIERI A., CHEREL Y., JAEGER A., CHURLAUD C., BUSTAMANTE P. Penguins as bioindicators of mercury contamination in the southern Indian Ocean: geographical and temporal trends. Environmental Pollution. 213, 195, 2017.

5. FREDERICK P., JAYASENA N. Altered pairing behaviour and reproductive success in white ibises exposed to environmentally relevant concentrations of methylmercury. Proceedings of the Royal Society of London Series B-biological Sciences. 278, 1851, 2011.

6. HARIS H., ARIS A.Z., Bin MOKHTAR M. Mercury and methylmercury distribution in the intertidal surface sediment of a heavily anthrophogenically impacted saltwater- mangrove-sediment interplay zone. Chemosphere. 166, 323, 2017.

7. HARIS H., ARIS A. Mercury distribution in Port Klang mangrove and estuarine sediment. From Sources to Solution. 187, 2014.

8. MASIH A., TANEJA A., SINGHVI R. Exposure profiles of mercury in human hair at a terai belt of North India. Environmental Geochemistry and Health. 38, 145, 2016.

9. LIN C. Y., LI P.Z., CHENG H.G., OUYANG W. Vertical distribution of lead and mercury in the wetland argialbolls of the Sanjiang Plain in Northeastern China. Plos One. 10, e0124294, 2015.

10. RAMOS-MIRAS J.J., ROCA-PEREZ L., GUZMANPALOMINO M., BOLUDA R., GIL C. Background levels and baseline values of available heavy metals in Mediterranean greenhouse soils (Spain). Journal of Geochemical Exploration. 110, 186, 2011.

11. IQBAL A., TABINDA A.B., YASAR A., MAHFOOZ, Y. Heavy Metal Uptake and Toxicity in Tissues of Commercially Important Freshwater Fish (Labeo rohita and Wallago attu) from the Indus River, Pakistan. Polish Journal of Environmental Studies. 26, 627, 2017.

12. AHMADPOUR M., HAI L.L., AHMADPOUR M., HOSEINI S.H., MASHROFEH A., BINKOWSKI L.J. Mercury concentration in the feathers of birds from various trophic levels in Fereydunkenar International wetland (Iran). Environmental Monitoring and Assessment. 188, 666, 2016.

13. BONANNO G., BORG J.A., DI MARTINO V. Levels of heavy metals in wetland and marine vascular plants and their biomonitoring potential: a comparative assessment. Science of the Total Environment. 576, 796, 2017.

14. ZHANG Y.R., WANG R.Q., XUE T., GE X.L., LIU J. Effects of Soil Properties and Flooding on the Mobility and Transformation of Mercury in a Temperate Riparian Wetland. Soil and Sediment Contamination. 24, 191, 2015.

15. KIM J., OH J. M. Assessment of trace metals in four bird species from Korea. Environmental Monitoring and Assessment. 185, 6847, 2013.

16. EVA T., SILLANPÄÄ S., SALMINEN J.P., NIKKINEN L., TUOMINEN A., TOIVONEN E., PIHLAJA K., LEHIKOINEN E. Environmental pollution affects the plumage color of great tit nestlings through carotenoid availability. EcoHealth. 5, 328, 2008.

17. ESPEJO W., CELIS J.E., GONZALEZ-ACUNA D., JARA S., BARRA R. Concentration of trace metals in excrements of two species of penguins from different locations of the Antarctic Peninsula. Polar Biology. 37, 675, 2014.

18. LEWIS S., FURNESS R. Mercury accumulation and excretion in laboratory reared black-headed gullLarus ridibundus chicks. Archives of Environmental Contamination and Toxicology. 21, 316, 1991.

19. AAZAMI J., ESMAILI-SARI A., BAHRAMIFAR N., GHASEMPOURI M., SAVABIEASFAHANI M. Mercury in Liver, Kidney, Feather and Muscle of Seabirds from Major Wetlands of the Caspian Sea, Iran. Bulletin of Environmental Contamination and Toxicology. 86, 657, 2011.

20. LIU X.D., ZHAO S.P., SUN L.G., YIN X.B., XIE Z.Q., HONGHAO L., WANG Y.H. P and trace metal contents in biomaterials, soils, sediments and plants in colony of redfooted booby (Sula sula) in the Dongdao Island of South China Sea. Chemosphere. 65, 707, 2006.

21. XU L.Q., LIU X.D., NIE Y.G. Trace elements $(\mathrm{Cu}, \mathrm{Zn}$, and $\mathrm{Hg}$ ) and delta $\mathrm{C}-13 /$ delta N-15 in seabird subfossils from three islands of the South China Sea and its implications. Environmental Monitoring and Assessment. 188, 274, 2016.

22. FANG F.M., WANG H.D., LIN Y.S. Spatial distribution, bioavailability, and health risk assessment of soil $\mathrm{Hg}$ in Wuhu urban area, China. Environmental Monitoring and Assessment. 179, 255, 2011.

23. COVELLI S., PROTOPSALTI I., ACQUAVITA A., SPERLE M., BONARDI M., EMILI A. Spatial variation, speciation and sedimentary records of mercury in the Guanabara Bay (Rio de Janeiro, Brazil). Continental Shelf Research. 35, 29, 2012.

24. ZHANG C., CHEN H., WANG D.Y., SUN R.G., ZHANG J.Y. Distribution and risk assessment of mercury species in soil of the water-level-fluctuating zone in the Three Gorges Reservoir. Environmental science. 35, 1060, 2014 [In Chinese].

25. WANG C., YUAN X.Y., CHEN Y., JI J.F., XI B.B. Quantification of contributions from different sources on heavy metals accumulation in the paddy soil from Suzhou area. Acta Scientiae Circumstantiae. 35, 3269, 2015 [In Chinese].

26. GARCIA-SEOANE R., VARELA Z., CARBALLEIRA A., ABOAL J.R., FERNANDEZ J.A. Temporal trends in mercury concentrations in raptor flight feathers stored in an environmental specimen bank in Galicia (NW Spain) between 2000 and 2013. Ecotoxicology. 26, 196, 2017.

27. MALLORY M.L., BRAUNE B.M., PROVENCHER J.F., CALLAGHAN D.B., GILCHRIST H.G., EDMONDS S.T., ALLARD K., O'DRISCOLL N.J. Mercury concentrations 
in feathers of marine birds in Arctic Canada. Marine Pollution Bulletin. 98, 308, 2015.

28. MONTEIRO L.R. Seabirds as monitors of mercury in the marine environment. Water, Air and Soil Pollution. 80, 851, 1996.

29. BURGER J., GOCHFELD M., SULLIVAN K., IRONS D. Mercury arsenic, cadmium, chromium lead, and selenium in feathers of pigeon guillemots (Cepphus columba) from Prince William Sound and the Aleutian Islands of Alaska. Science of the Total Environment. 387, 175, 2007.

30. MOREL F.M.M., KRAEPIEL A.M.L., AMYOT M. The chemical cycle and bioaccumulation of mercury. Annual Review of Ecology Evolution and Systematics. 29, 543, 1998.

31. COSTA R.A., EEVA T., EIRA C., VAQUEIRO J., VINGADA J.V. Assessing heavy metal pollution using Great Tits (Parus major): Feathers and Excrements from Nestlings and Adults. 185, 5339, 2013.

32. CARDONA A.F.R., MOLINA M.T.F., BAENA J.P. Variations of seasonal and spatial $\mathrm{Hg}, \mathrm{Pb}, \mathrm{Cr}$ and organic matter contents in Ayapel Flood Plain Lake sediments,
Cordoba, northwest Colombia. Revista Facultad De Ingenieria-Universidad De Antioquia. 69, 244, 2013.

33. OBRIST D., JOHNSON D.W., LINDBERG S.E., LUO Y., HARARUK O., BRACHO R., BATTLES J.J., DAIL D.B., EDMONDS R.L., TODD D.E. Mercury distribution across 14 US forests. Part I: Spatial patterns of concentrations in biomass, litter, and soils. Environmental Science and Technology. 45, 3974, 2011.

34. CHEN L.G., XU Z.C., DING X.Y., ZHANG W. D., HUANG Y.M., FAN R.F., SUN J.R., LIU M., QIAN D L., FENG Y.B. Spatial trend and pollution assessment of total mercury and methylmercury pollution in the Pearl River Delta soil, South China. Chemosphere. 88, 612, 2012 .

35. HAITZER M., AIKEN G.R., RYAN J.N. Binding of mercury (II) to dissolved organic matter. The role of the mercury-to-DOM concentration ratio. Environmental Science and Technology. 36, 3564, 2002.

36. DONG Z., WU L., KETTLEWELL B., CALDWELL C.D., LAYZELL D.B. Hydrogen fertilization of soils - is this a benefit of legumes in rotation? Plant Cell and Environment. 26, 1875, 2003. 
